$$
\begin{array}{llll}
\text { 冨山明 男*1, 宋 明 } \text { 良 }^{* 2} \\
\text { 吉川秀 雄*3, 坂 口 }
\end{array}
$$

\title{
Three-Dimensional Detailed Numerical Simulation of Bubbly Flow in Vertical Square Duct
}

\author{
Akio TOMIYAMA, Akira SOU, \\ Hideo YOSHIKAWA and Tadashi SAKAGUCHI
}

\begin{abstract}
A three-dimensional detailed numerical simulation for flows with bubbles was conducted in the present study. The simulation was based on the local instantaneous field equations of the gas liquid two-phase flow and on the interface tracking method of the volume of fluid method. The velocity and pressure fields were calculated using the modified SOLA method. The validity of the numerical method was confirmed by the comparison between measured and calculated terminal velocities and shapes of a single bubble in an infinite stagnant liquid for a wide range of the Morton number and the Eötvös number. Then, laminar bubbly flow in a vertical square duct was analyzed by making use of a periodic boundary condition. As a result, two typical void distributions, the wall peak and core peak, were obtained by varying the Eötvös number. This result agreed well with existing experimen. tal data.
\end{abstract}

Key Words: Multiphase Flow, Computational Fluid Dynamics, Multidimensional Flow, Bubble Shape, Terminal Rising Velocity, Bubbly Flow, Void Distribution

\section{1. 緒言}

従来, 気液二相流の数値解析には，二流体モデル等 の平均化された基礎方程式(1)に気液間および各相と 流路壁間の相互作用を表寸構成方程式を組合せる手法 が用いられてきた。本手法は複雑な配管系内(2)や多次 元空間内の過渡気液二相流現象 ${ }^{(3)}$ を比較的短時間で 解析できる能力を有するため, 原子炉の安全性解析等 の種々の工業上の問題に適用されている。しかしなが ら, 現在までに提案されている構成方程式の大部分は 実験相関式であるため，実験で得られる以上の物理的 な情報を本手法から抽出するのは困難である。一方， 近年の計算機速度・容量の飛躍的発展により, 瞬時局 所的な気液二相流の基礎方程式(1)に基づく，より詳細 な数値解析の実現性が高まってきた。実験相関式を必 要としない瞬時局所的な基礎方程式に基づく数值解析 が実現できれば，気液二相流のモデル化に役立つ知見 を数值実験的に提供できる可能性がある。

このため著者ら(4) (8) は, 瞬時局所的基礎方程式に

* 原稿受付 平成 6 年 1 月 20 日.

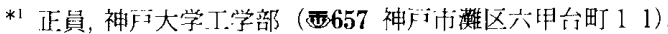

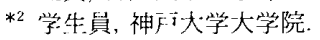

*3 正員, (株) 構造計画研究所（画164 東京都中野区本町 438 13).
基づく数值解法の一つであるVolume of Fluid (VOF) 法(9)(10) を用いて, 気泡を含む流れの詳細解析 の実現性を，単一気泡や単一大気泡，直列二気氾の干 涉等の解析を通して検討してきた。 その結果, 気泡の 連動に及ぼす種々の因子のうち，（1）気泡径，（2）密 度, 粘性係数, 表面張力等の気液各相の物性值，(3) 重力加速度，(4)管壁の存在，(5)気泡が自儿生成す る渦と気泡との干涉，(6)気泡外部の渦(液相の速度 こう配）との干渉，（7）他の気泡との液相を介しての 間接的な干涉に関して，良好に予測できることを確認 した，気相体積率が小さく，気泡の命体や分裂がない 牕流条件下の垂直管内気泡流は，以上の过子に支配さ れると考えられる。したがって, 高速大谷最の計算機 環境さえ整えば，多数の気泡を含む気泡流の詳細解析 がー十分実現できるという見通しが得られたといえる。

そこで本報では，まず，現実的な管内気泡流の詳細 解析を実施するためにVOF 法を三次元解析用に搪張 した。次に, 静止液中単一気泡の形状と終端速度に関 する帮験結果と計算結果の比較検討により昖張した手 法の妥当性を検討した。さらに，垂淔く形ダクト内層 流気泡流の解析を行い, 瞬時局所的な基礎方程式系に 基の゙く気液二相気泡流の詳細解析の笑現性を検討し た。 


\section{2. 基礎方程式および数值解法}

非玨縮性気液二相流の各相に対して瞬時局所的に成 立する以下の三次元 $(x, y, z)$ 座標系における質量お よび運動量の保存式を基礎方程式に用いる。

$\operatorname{div} \boldsymbol{V}_{k}=0$

$\rho \frac{D \boldsymbol{V}_{k}}{D t}=-\operatorname{grad} p+\rho \boldsymbol{g}+\mu_{k} \operatorname{div} \operatorname{grad} \boldsymbol{V}_{k}$

ここで, $\boldsymbol{V}=(u, v, w)$ は速度べクトル, $t$ は時刻, $p$ は压力, $\boldsymbol{g}$ は単位質量当たりの体積力, $\mu$ は粘性係数, $D / D t$ は実質微分を，添字の $k$ は気相 $(G)$ または液相 (L) を表す.VOF 法と同様に計算セルにおける液相体 積率 $F$ により密度 $\rho$ を次式で定義する.

$$
\rho=F \rho_{L}+(1-F) \rho_{G}
$$

したがって, $F=0$ あるいは $F=10$ 場合には, 式 （2）は気相単相流あるいは液相単相流に対するナビ エ・ストークスの式と同じになる。一方， $F$ の値が $0<$ $F<1$ のセルは気液界面が存在する，界面セルの周 囲のセルの $F$ の值から，まず界面セル内の界面位置 と界面の曲率 $\chi$ (二つの主曲率 $\chi_{1}, \chi_{2}$ の和)を求める. 微分幾何学の基本的公式(11)より $x$ は次式で与えられ る.

$$
x=x_{1}+x_{2}=\frac{R\left(1+Q^{2}\right)-2 P Q S+T\left(1+P^{2}\right)}{\left(1+P^{2}+Q^{2}\right)^{3 / 2}}
$$

上式において，仮に界面が $x-y$ 平面にほぼ平行で計 算セルの底面から界面までの高さが $z=h(x, y)$ と表 される場合, $P, Q, R, S, T$ は次式で与えられる.

$$
\begin{aligned}
& P=\frac{\partial h}{\partial x}, Q=\frac{\partial h}{\partial y}, R=\frac{\partial^{2} h}{\partial x^{2}}, \\
& S=\frac{\partial^{2} h}{\partial x \partial y}, T=\frac{\partial^{2} h}{\partial y^{2}}
\end{aligned}
$$

式(5)を中心差分により離散化し, 式(4)に代入すれ ば曲率の計算式が得られる。界面が $y-z$ 平面，あるい は $z-x$ 平面に近い場合も式 (4)，（5) と同様な公式 から曲率を計算できる.得られた $れ$ よ表面張力 $\sigma$ に よる圧力 $p_{s}$ を,

$$
p_{s}=\chi \sigma
$$

により求める， ps は界面に垂直で，かつ曲率中心の方 向に加わる。そこで，図1に示すように曲率中心を向 いている界面の面積ベクトルを $S$ とすると, 界面セ ルにおける表面張力による単位体積当たりの力 $\boldsymbol{f}_{s}$ は 次式で与えられる。

$$
\boldsymbol{f}_{s}=\frac{p_{s} \boldsymbol{S}}{\Delta x \Delta y}
$$

ここで, $\Delta x, \Delta y, \Delta z$ はおのおの $x, y, z$ 方向のセル幅

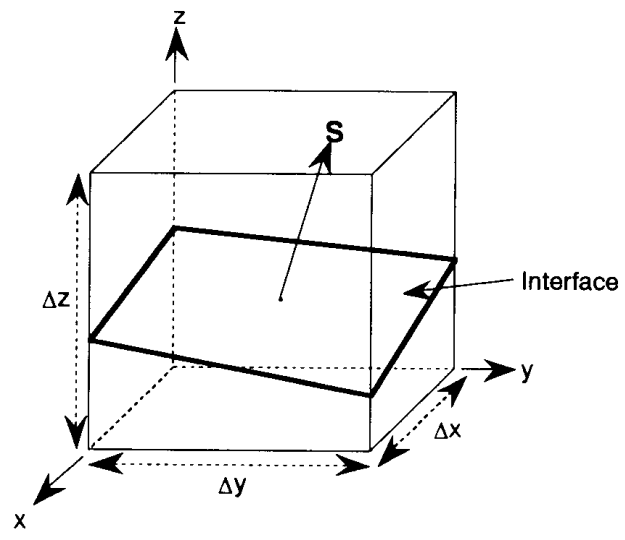

図 1 界面セルの模式図

を表す。界面セルに扔いては，式（7)を式（2）の右辺 に加えることにより，表面張力が压力場と速度場に及 ぼす影響を考虑する。

一方, 液相体積率 $F$ は, 以下の液相の体積保存則を 満たす。

$$
\frac{\partial F}{\partial t}+\operatorname{div}\left(F \boldsymbol{V}_{L}\right)=0
$$

上式を三次元化したドナーアクセプター法(9) で解き， 界面位置の時間変化を求める.

なお，式(1)，(2)の計算には既報 ${ }^{(12)}$ に提示した改 良SOLA 法を使用した。改良 SOLA 法は, SOLA (Solution Algorithm) 法(10)における速度場と压力場 の同時反復解法に圧力の境界条件を適切に組み込むこ とにより，計算速度を数倍に向上させた解法である。

\section{3. 静止液中単一気泡の解析}

本章では，作成した計算プログラムの妥当性を検証 するために, 無限静止液中単一気泡の終端速度と形状 に関する既存の実験結果 ${ }^{(13)(14)}$ と計算結果を比較す る. 図 2 にBhaga-Weber ${ }^{(13)}$ による無限静止液中単一 気泡の形状と終端速度に関する相関図を示す。本図は， Grace $^{(14)}$ が提示した単一気泡の形状と終端速度の相 関図を改良し，気泡形状をより細かく分類したもので ある。ただし，終端速度に関しては Graceの相関図と 同じである. 図 2 中の無次元数 $E o, M, R e$ は扔のおの 以下の諸式で定義されるエトベス数, モルトン数, 気 泡レイノルズ数を意味する。

$$
\begin{aligned}
& E_{O}=\frac{g\left(\rho_{L}-\rho_{G}\right) d^{2}}{\sigma} \\
& M=\frac{g \mu_{L}^{4}\left(\rho_{L}-\rho_{G}\right)}{\rho_{L}^{2} \sigma^{3}} \\
& \operatorname{Re}=\frac{\rho_{L} V_{t} d}{\mu_{L}} \ldots \ldots . . .
\end{aligned}
$$

ここで, $g$ は重力加速度, $d$ は気泡の体積等価淔径, $\sigma$ 


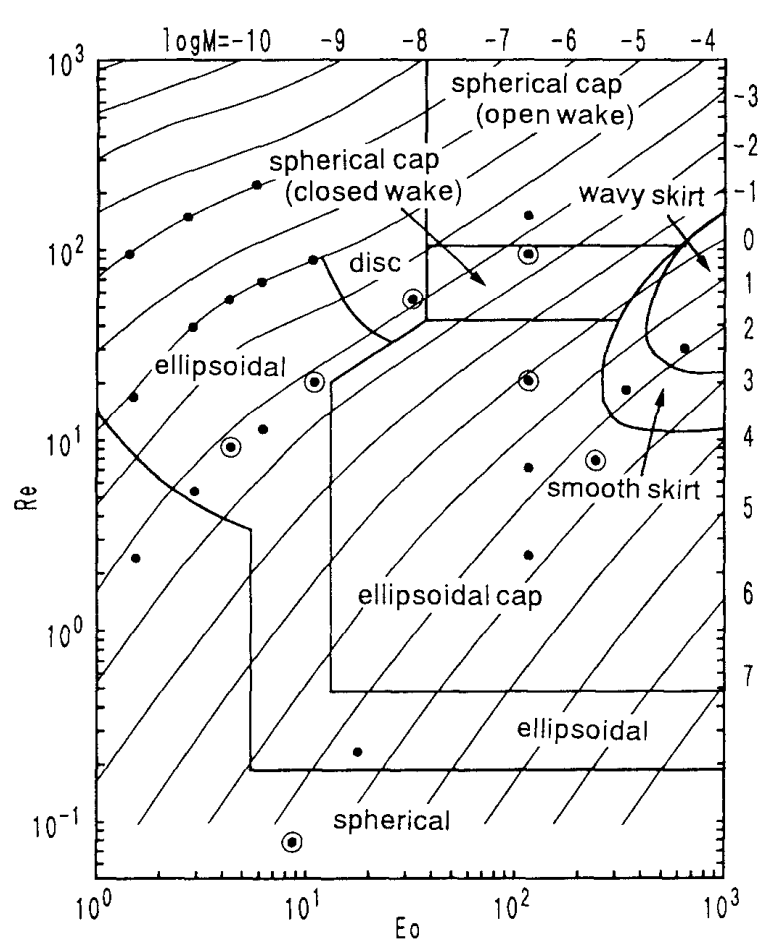

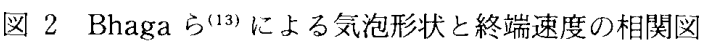
(黒丸：終端速度の比較条件, 白丸：形状の比較 条件)

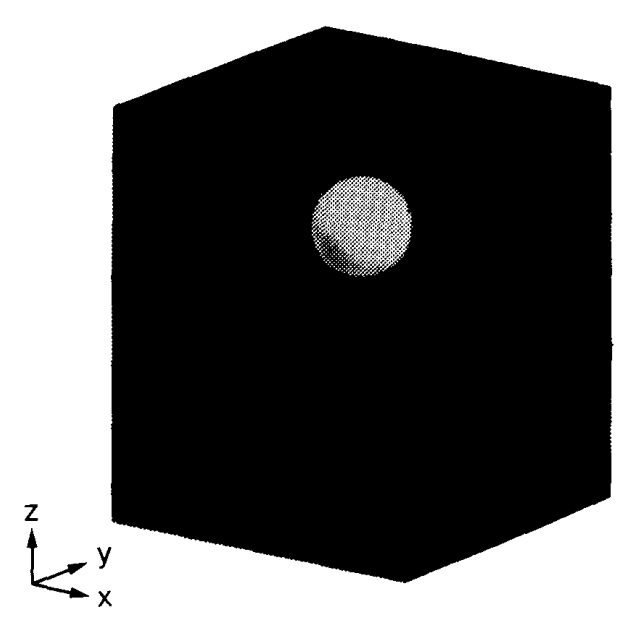

图 3 計算領域と初期気泡形状

は表面張力, $V_{t}$ は終端速度を表す。 $E o$ は浮力と表面 張力の比を, $M$ は各相を構成する物性值の影響を表 寸. 図 2 上り, 気泡の無次元終端速度 $R e$ と形状が $E o$ と $M$ により一意に定まることがわかる.

図 3 に計算の初期条件を示寸. 初期気泡形状は球形 とし，気泡直径 $d$ 当たりに10〜14 セルを与えた．特 に, 気泡の変形が大きい場合に, 気泡当たりのセル数 を多くした， $x, y, z$ 方向の計算領域の長さは，おのお の $4 d, 4 d, 4.5 d$ とした. したがって, 気泡直径当たり に14セルを与えた場合の総セル数は， $(56+2)(56$

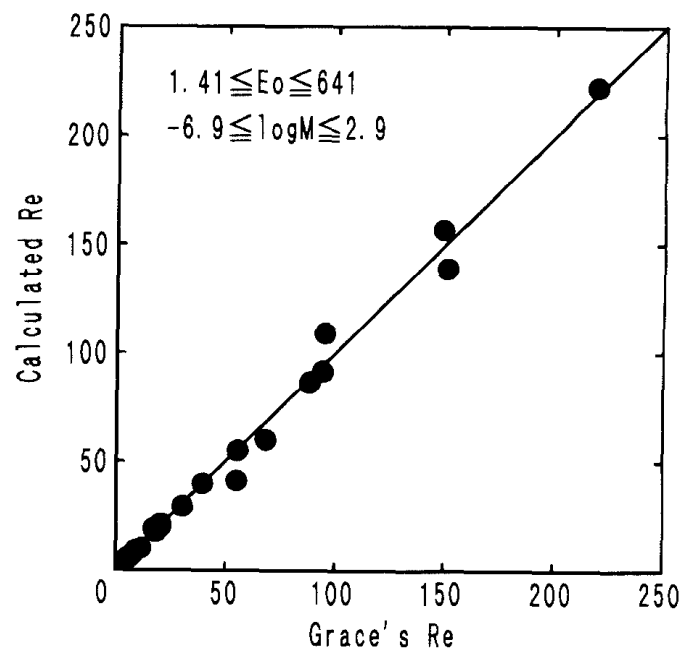

図 4 Graceの無次元終端速度と計算結果の比較

$+2)(63+2)=218660$ である.ここで，＋2 は境界条件 指定用に計算領域の外側に設けた仮想セルの奇与を表 す.上部境界から一様速度 $V_{\text {in }}$ で液相を下゙方に流入さ

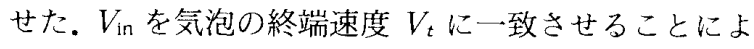
り, 計算領域の中心部から気泡が移動しないようにし た。側面境界と下部境界は, 連続流出条件とした。本境 界条件により，無限静止液中の単一気泡の挙動を速度 $V_{t}$ で上昇する座標系から観察した場合の解析が実現 できる．終端速度の計算值は計算領域内の気泡先端部 の $z$ 方向の移動速度に $V_{\text {in }}$ を加えて求めた。 また，気 泡形状が時間的に変化しなくなった際の形状を, 気泡 形状計算結果とした。

図 2 中に黒丸で示した流動条件において, 気泡の無 次元終端速度 Re の計算值と Grace の相関図の値を

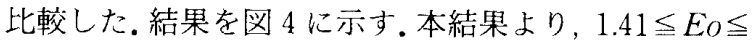
$641,-6.9 \leqq \log M \leqq 2.9$ の広範囲の流動条件において 終端速度を精度よく予測できることが確認できた。

気泡形状の実験結果と計算結果を図 5 に示す。図 2 中に白丸で示してあるように，比較した流動条件は層 流条件下の種々の気泡形状に対応している. 図 5(a), $(\mathrm{d}) \sim(\mathrm{g})$ の写真は Bhaga らの文献 (13) から引用し たものである。一方, 図 5 (b)，(c)の写真は空気とグ リセリン水溶液を用いて著者らが実験した結果であ る. 本图上り $E O$ と $M$ による気泡形状の変化を良好に 予測できていることがわかる。ただし，艮 $5(\mathrm{~d}),(\mathrm{g})$ のように気泡が極端に偏平化する条件では, 計算結果 と実験結果の相異がやや大きい。これは，計算機のメ モリーと演算速度の制約から十分なセル数を使用でき なかったことが原因と考えられる。

以上, 無限静止液中単一気泡の形状と終端速度に及 添すEOと $M$ の影響を, 本計算手法により良好に予 

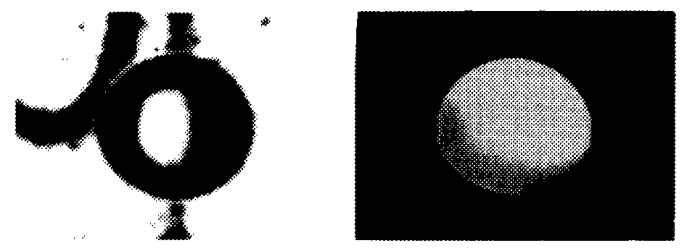

(a) $E 0=8.67, M=7.11$

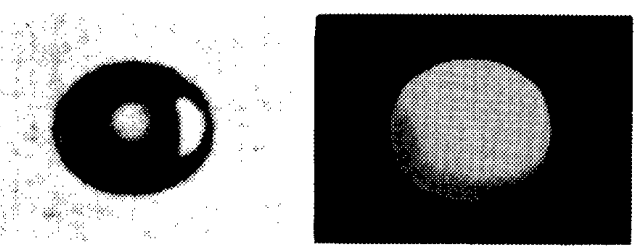

(b) $E o=4.38, M=2.98 \times 10^{-3}$
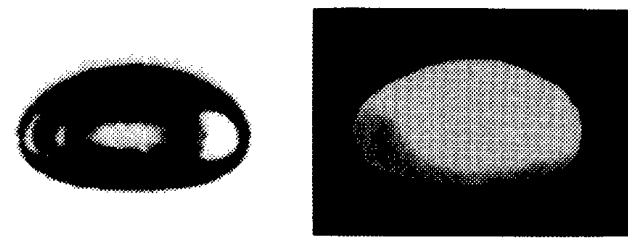

(c) $E 0=10.94, M=2.98 \times 10^{3}$

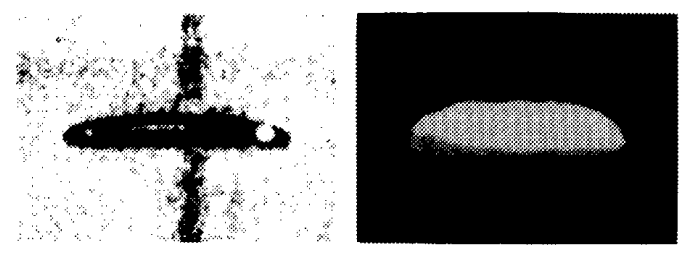

(d) $E o=32.2, M=8.20 \times 10^{-4}$
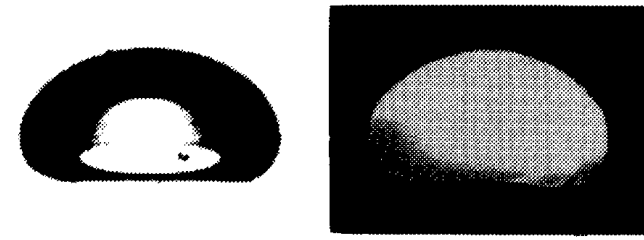

(e) $E(=243, M=266$

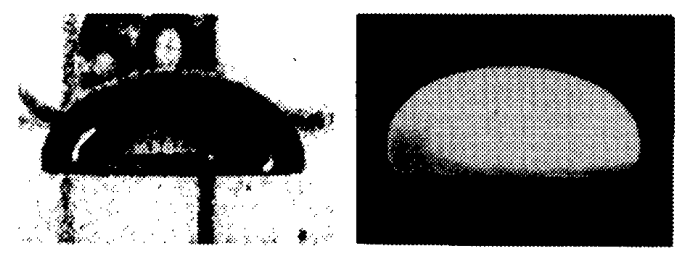

(f) $E \circlearrowleft=116, M=1.31$

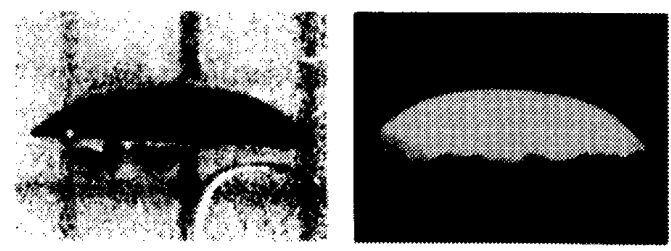

(g) $\quad E o=115, M=4.63 \times 10^{-3}$

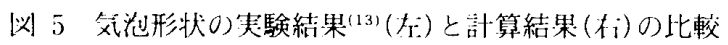
[(b)，(c)在除き文献(13)上り引用]

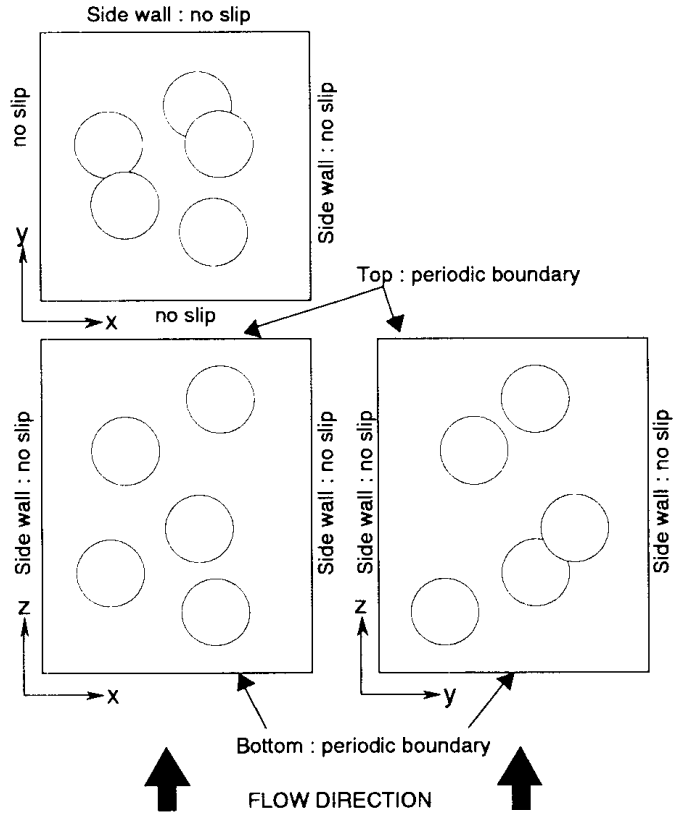

図 6 初期条件と境界条件

测できることが確認できた。

\section{4. ダクト内気泡流の解析}

$4 \cdot 1$ 計算体系および計算条件図 6 に計算体系 および気泡の初期配置を三面図の形式で示す。ダクト 壁面には滑りなし境界条件を，上下境界には周期的境 界条件を用いた(圧力に関しては，玨力こう配が上下 境界で一致するように設定した)。したがって，上部か ら流出した気泡や液体は下部から再進入する。流路断 面は一辺の長さが $4 d$ の正方形とした.また，流れ方向 の距離は $5 d$ とした。 $x, y, z$ 方向をおのおの 48,48 , 60 の等間隔セルに分割し，境界条件用仮想セルを含め て計 157500 セルを使用した。気泡の初期形状は球形 とし，気泡直径当たりに12セルを与えた。計算領域内 の気泡数は 5 個とし領域内の体積平均ボイド率を $3.3 \%$ とした。

局所全体積流束分布の初期值には層流の分布を用い た。ここで，局所全体積流束 $\boldsymbol{J}$ は次式で定義される量 である。

$$
\boldsymbol{J}=F \boldsymbol{V}_{L}+(1-F) \boldsymbol{V}_{G}=\left(J_{x}, J_{y}, J_{z}\right)
$$

上式において $J_{x}, J_{y}$ の初期值は零とした， $J_{z}$ は $z$ 方向 の層流条件における運動量保存式,

$$
0=-\frac{d p}{d z}-\rho g+\mu_{L}\left(\frac{\partial^{2} J_{z}}{\partial x^{2}}+\frac{\partial^{2} J_{z}}{\partial y^{2}}\right) \cdots
$$

を利用して与えた。なお，厤力は流路断面内で一定と 仮定し,$d p / d z$ を $z$ みの関数と考えている。式(13) は以下のポアソンカ程式の境界值問題を構成してい 
る。

$$
\begin{aligned}
& \frac{\partial^{2} J_{z}}{\partial x^{2}}+\frac{\partial^{2} J_{z}}{\partial y^{2}}=G \\
& J_{z}=0 \text { at } x=0, x=L, y=0, \text { and } y=L
\end{aligned}
$$

ただし，Lは正方形ダクトの一辺の長さ, ソース項 $G$ は

$$
G=\frac{1}{\mu_{L}}\left(\frac{d p}{d z}+\rho g\right)
$$

である。ここで, 流路断面内で圧力が一定と仮定して いるので, 密度 $\rho$ を断面平均値,

$$
\begin{aligned}
\rho & =\rho(z)=\frac{1}{L^{2}} \int_{L^{2}}\left\{\rho_{G}[1-F(x, y, z)]\right. \\
& \left.+\rho_{L} F(x, y, z)\right\} d x d y \quad \cdots \cdots \cdots \ldots \ldots \ldots \ldots \ldots \ldots
\end{aligned}
$$

と考えれば，式(16)の $G$ は流路断面内で一定と仮定 できる。式(14)は線形偏微分方程式であり，かつ境界 条件式(15)が同次形なので，ソース項 $G$ が定数倍に なった場合の解 $J_{z}(x, y)$ はその分布形状を保ったま ま定数倍になる。そこで，まず $G=-1$ として式(14)， (15)の数值解を求め, その数值解を定数倍して所定の 流量になるように調節した。仮に $\beta$ 倍して，全体積流 束分布を設定した場合，式(16)から压力こう配は次式 で与えられる。

$$
\frac{d p}{d z}=-\left(\mu_{L} \beta+\rho g\right)
$$

上式の右辺第 1 項は摩擦圧力降下を, 第 2 項は重力に よる圧力降下を表す。一般に, 二相流の摩擦圧力降下 は単相流とは異なることが知られている(1).したがつ て，式(18)功決まる压力こう配は，初期に設定した 全体積流量を定常的に駆動する圧力こう配とは完全に は一致せず，定常的流動を実現できない.そこで，二严相 流摩擦増倍係数 $\Phi^{2}$ を用いて, 式(18)を以下のように 修正する。

$$
\frac{d p}{d z}=-\left(\mu_{L} \beta \Phi^{2}+\rho g\right)
$$

二相流摩擦増倍係数をあらかじめ正確に推定すること は困難である。そこで，まず $\Phi^{2} を 1$ として式(19)から 初期圧力分布を設定し，流れ場の時間発展を計算す る。その結果，断面平均全体積流束が初期の断面平均
全体積流束よりも時間的に減少(増加)する場合には， $\Phi^{2}$ を増加(減少)させて再び式(19)方初期压力分布 を計算し初期状態から過渡計算を再試するという試行 錯誤的方法を用いた。なお，断面平均全体積流束が時 間的に変化し，初期值の $\pm 3 \%$ を超えた場合は，計算 を中止した。

次に，数值計算上のパラメータを整理しておくこ れまでの研究(4) (8) で示してきたように, 気泡の挙動 は二つの無次元数 $E O$ と $M$ によって大きく変化する. また，Eと $M$ 以外の垂直管内磨流気泡流の支配因子 としては, 流路形状, 体積平均気相体積率, 断面平均 体積流束が挙げられる。このうち，計算の都合上，流路 形状と体積平均ボイド率は固定しているので, 残され た因子は平均体積流束である。そこで，数值計算トの パラメータとして, $E o, M$, およびダクト中心軸上の 局所全体積流束 $J_{z \max }$ の無次元值,

$$
J_{z \max }^{*}=\frac{J_{z \max }}{V_{t}}
$$

の初期値を用いることにした。

尌算にはワークステーション $\mathrm{DEC} 3000 \mathrm{AXP}$ model 400(ピーク性能=133 MFLOPS, LINPACK 倍 精度 $(100 \times 100)=26.4)$ を用いた。また，計算結果の描 画処理には画像処理ソフトAVS (Application Visualization System) を用いた。

$4 \cdot 2$ 計算結果および考察 まず, $E o=5, \log M$ $=-3, J_{z \max }^{*}=0.5$ の条件で計算を行った。図 2 からわ かるように, $E O=5, \log M=-3$ に㧍ける無限静止液 中単一気泡の形状は球あるいはだ円体である．常温常 四济水・空気系垂直管内気泡流において気泡が球形や だけ形となるのは，等価直径 $2 \sim 3 \mathrm{~mm}$ 程度の小さな 体積の気氾に対応する。このような小気泡计管壁付近 を流動しやすく，いわゆるくら形ボイド分布を形成す ることが知られている(15)。 また，液相流速が大きいほ ど，管壁付近を小気泡が流動しや寸いことも知られて いる(16).

脳 7，8に気泡の形状と配置の時間変化に関する計 算結果を示寸。図 7 は流れ場を上部から見た図, 図 8

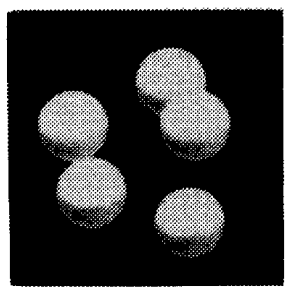

$t^{\star}=0.0$

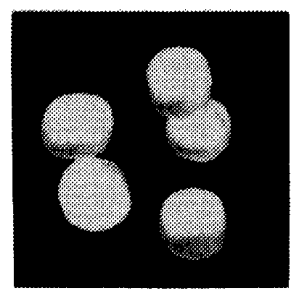

$t^{\star}=2.0$

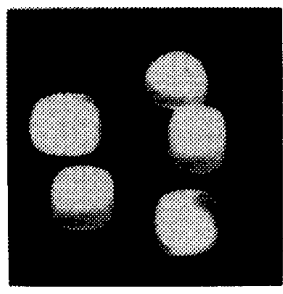

$t^{\star}=4.0$

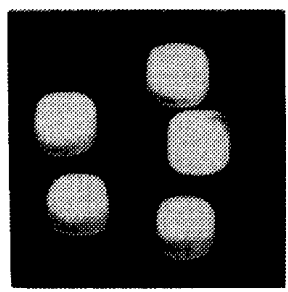

$t^{\star}=6.0$

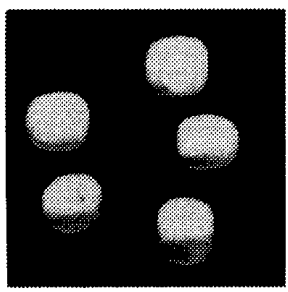

$t^{\star}=8.0$

図 7 ダクトト部から見た気泡の形状と配置の時間变化 $\left(E_{0}=5, \log M=-3, J_{z \max }^{*}=0.5\right)$ 

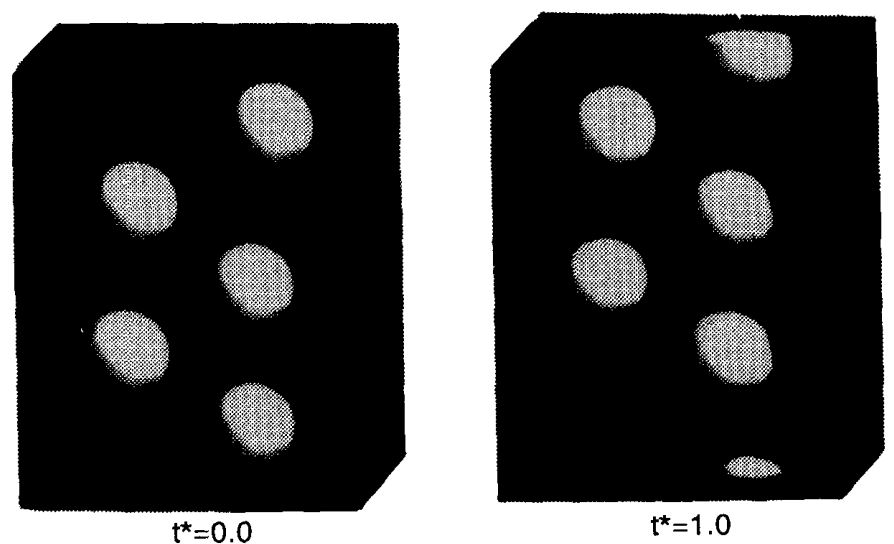

$t^{*}=1.0$

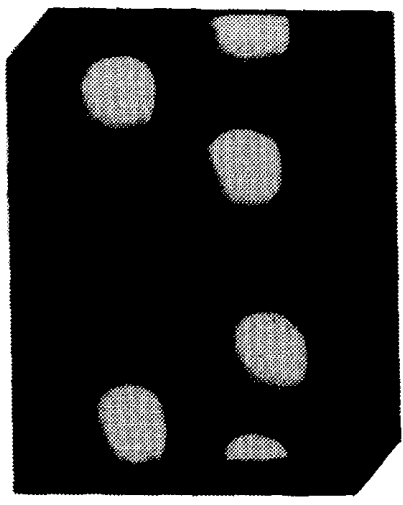

$t^{\star}=3.0$

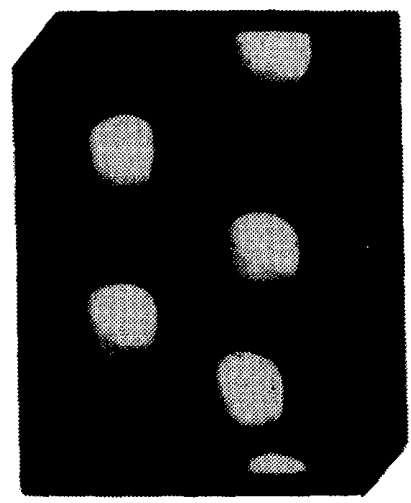

$t^{\star}=6.0$

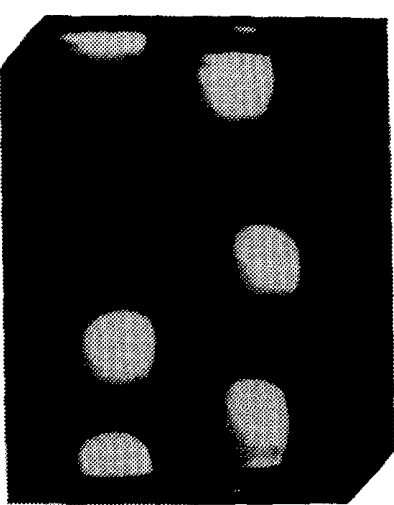

$t^{\star}=4.0$

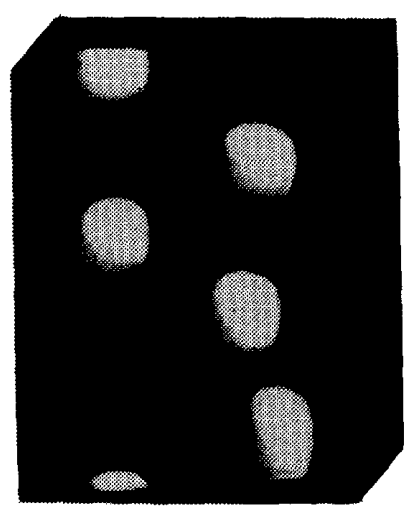

$t^{\star}=7.0$

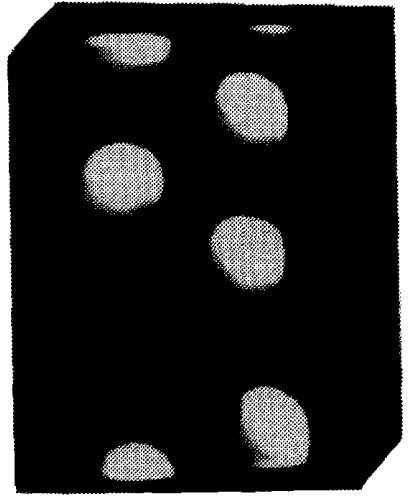

$t^{\star}=2.0$
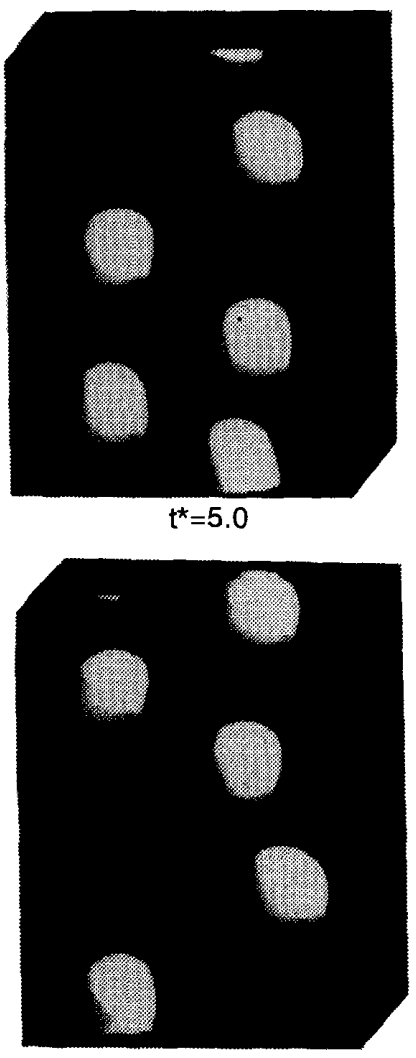

$t^{\star}=8.0$

図 8 斜め上部から見大気泡の形状と配圆の時間変化 $\left(E O=5, \log M=-3, J_{z \max }^{*}=0.5\right)$

は斜め上部から見た図である。図 $7,80 t^{*}$ は無次元 時間,

$$
t^{*}=\frac{V_{t} t}{d}
$$

である。また，計算に使用した時間刻み幅 $\Delta t^{*}$ は約 $10^{-4}$ であり，約 100000 サイクルの時間更新を行って いる。龱 7 より、時間の経過に伴い気泡が管壁のほう に移動し，くら形ボイド分布が形成されていることが わかる。また，上部から見た気泡形状が四角形に近い 形となっている。この形状は，3 章で行った無限静、上 液中单一気泡の解析では生じなかった形であり，ダク

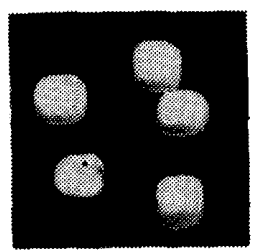

(a) $J_{2 \max }^{*}=0.25$

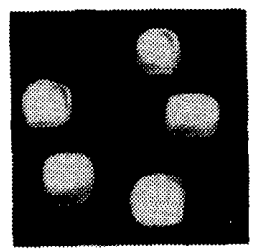

(b) $J_{2 \max }^{*}=0.5$

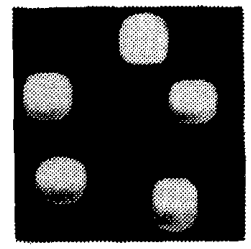

(c) $\int_{2 \min x}^{*}=1.0$
図 9 全体積流束が気泡配置に及ほ寸影響 $\left(E O=5, \log M=-3, t^{*}=10\right)$

トの側壁の影響により生じたものと考えられる。一力， 闵8より気泡が管壁付近に移動するにつれ，管壁付近 の急峻な液相速度こう配の影皐を受けて，傾いた長軸 
をもつ回転だ円体に変形していく傾向が見られる．应 7 に扔いて，時間の経過とともに気泡の投影面積が減 少しているのは,この変形が原因である.
図 9(a) ( c ) に, 全体積流束 $J_{z \max }^{*}$ が気沱行布に 及涩す影響を調べた結果を示す。Eoと $M$ は図 7 と同 じである。また，図 9 (a)，(b)，(c)ともに $t^{*}=10$

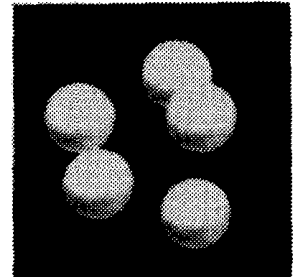

$t^{\star}=0.0$

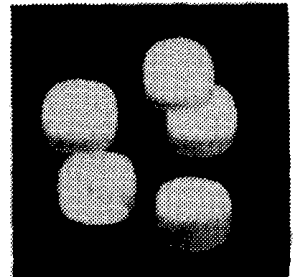

$t^{\star}=2.0$

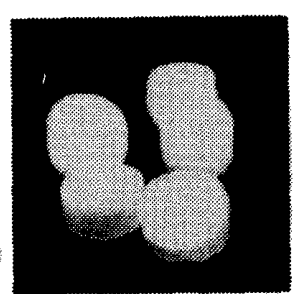

$t^{\star}=4.0$

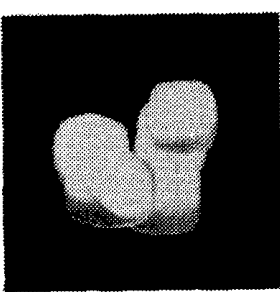

$t^{\star}=6.0$

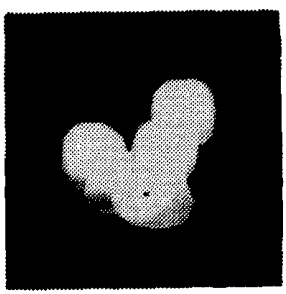

$t^{\star}=8.0$

图 10 ダクト上部から見た気泡の形状と配置の時間変化 $\left(E o=20, \log M=-3, J_{z \max }^{*}=0.5\right)$

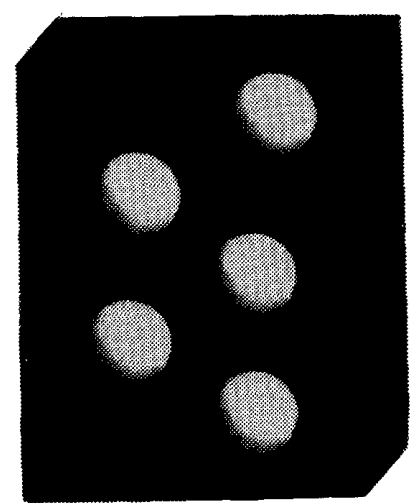

$t^{\star}=0.0$

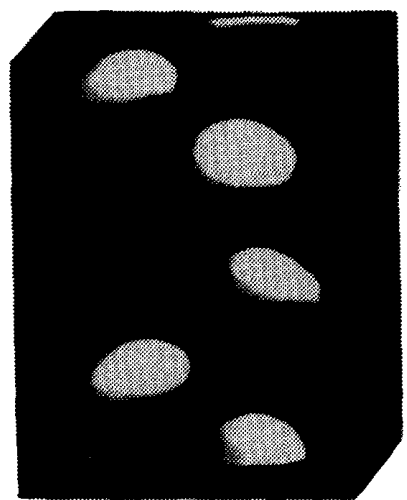

$t^{\star}=3.0$

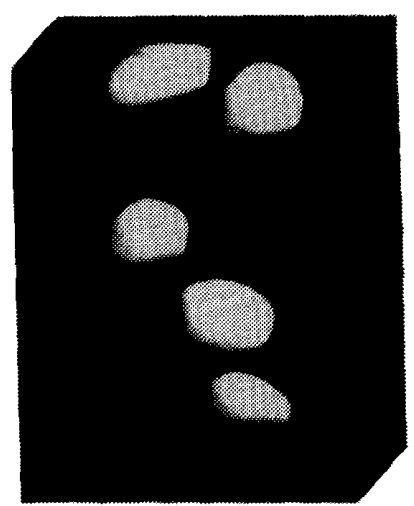

$t^{\star}=6.0$

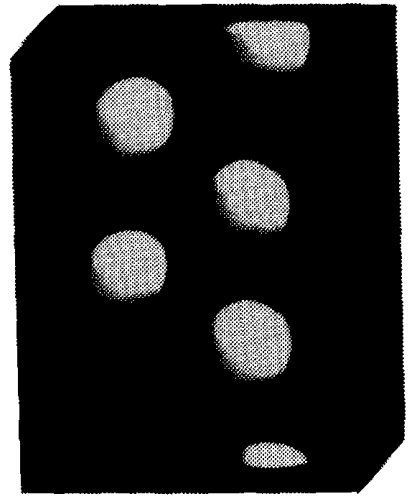

$t^{\star}=1.0$

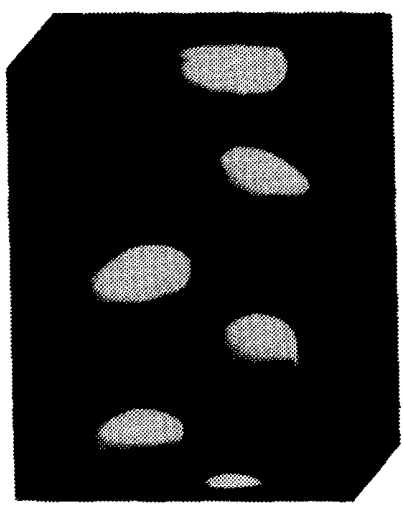

$t^{\star}=4.0$

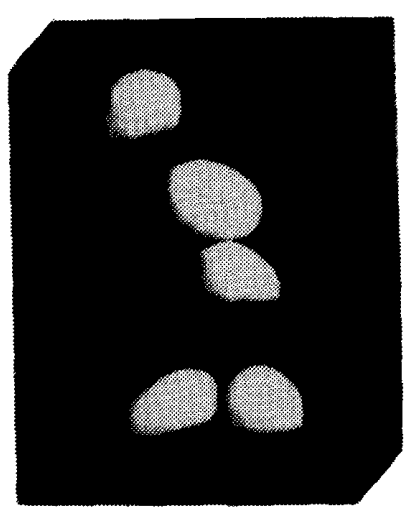

$t^{\star}=7.0$

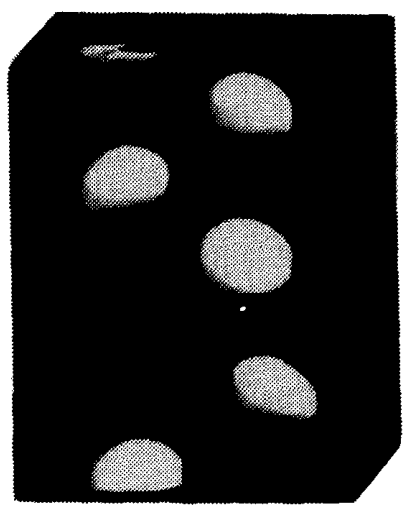

$t^{*}=2.0$

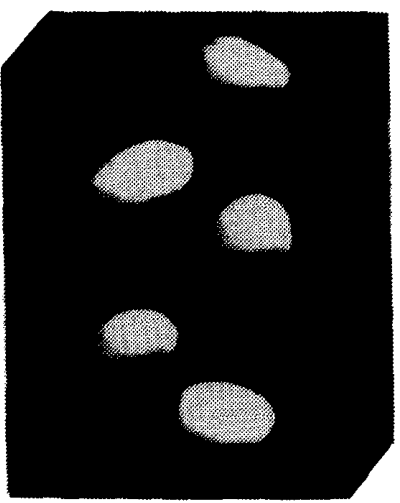

$t^{\star}=5.0$

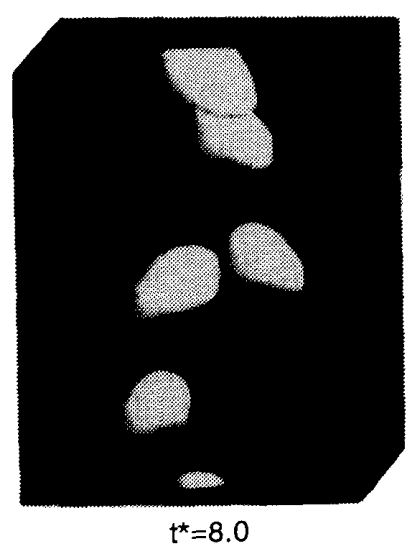

図 11 斜め上部から見た気泡の形状と配置の時間变化 $\left(E_{0}=20, \log M=-3, J_{z \max }^{*}=0.5\right)$ 


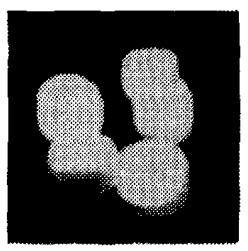

(a) $J_{z \max }^{*}=0.5$

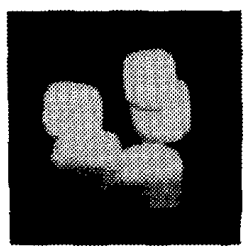

(b) $J_{z \max }^{*}=1.0$
図 12 全体積流束が気泡配置に及ほす影響 ( $\left.E o=20, \log M=-3, t^{*}=4.0\right)$

における気泡配置を表している。本図より，Jzmax が大 きいほど気泡が管壁方向に移動する傾向が強いことが うかる。この傾向は既存の実験結果(16) と一致してい る.

次に, $E_{O}=20, \log M=-3, J z_{\text {max }}^{*}=0.5$ の計算結果 を図 10,11 に示す. Eo 以外は図 7, 8 と同じである. $E_{O}=20, \log M=-3$ におる無限静止液中単一気泡 の形状はだ円状〜ディスク状である，常温常圧の水・ 空気系垂直管内気泡流において，ディスク形状となる 気泡は直径 4 5 mm 以上の大きな体積の気泡に対応 する.この場合，管中心部付近を気泡が流動するコア 形ボイド分布となることが知られている(15). 図 10 よ り，時間の経過に伴い気泡がダクト中心付近に移動し， コア形ボイド分布が形成されていることがわかる。 ま た，図 $11 よ り$ 気泡が液相速度こう配の影響を受けて 翼形に変形していく過程が見られる。この変形過程は， 一様速度こう配中の単一気泡の形状変化に関寸る仮屋 崎(17) の実験結果と一致している，図 12 に, 全体積流 束 $J_{z \max }^{*}$ が気泡分布に及ぼす影響を示す。図 9 に示し た $E O=5$ の場合より顕著ではないが, 管中心部に気 泡が移動する傾向が，J每ax が大きいほど強いことが わかる.なお, $J_{z \max }^{*}=1.0$ の場合の気泡の投影面積が小 さいのは, 液相速度こう配による気泡の変形が大きい ためである。

以上，瞬時局所的な基礎方程式系に基づく三次元詳 細解析により，垂直管内気泡流における二つの典型的 ボイド分布が予測できることを実証できた。

\section{5. 結言}

本研究では，瞬時局所的な基礎方程式系に基づく気 泡流の三次元詳細解析を目的として, VOF 法と改良 SOLA 法に基づく三次元気液二相流解析プログラム を作成し, 無限静止液中単一気泡と垂直く形ダクト内
層流気泡流の解析を行ったそその結果，以下の結論を 得た。

（1）本手法により，層流条件下の広範囲のエトべ ス数 $E_{O}$ とモルトン数 $M$ において, 無限静止液中の 単一気泡の終端速度と形状を良好に予測できることを 確䜑した。

（2）周期境界条件，および重力と壁面摩擦による 二相流の圧力降下を考慮した圧力分布の初期条件を利 用することにより，垂直ダクト内気泡流の解析を実現 させた。

（3）気泡流解析により，気泡径が小さく表面張力 が大きな $E o=5$ の条件ではくら形ボイド分布が，気 泡径が大きく表面張力が小さな $E o=20$ の条件ではコ ア形ボイド分布が得られることを示した。また，流量 が大きいほど各分布の特徵が顕著に現れるという計算 結果が得られた。これらの結果は既存の実験結果と一 致している。

以上，本研究により瞬時局所的基礎方程式系に基づ く気液二相気泡流の詳細解析が実現できることを実証 できた。なお，計算に協力された(株)構造計画研究所 の豊岡篤氏, Ljubljana大学のI. Zun 教授, Josef Stefan Institute の V. Alkalaj 氏に感謝する。

\section{文献}

(1) Delhaye, J. M., Giot, M. and Riethmuller, M. L., Thermo-Hydraulics of Two-Phase Systems for Indus. trial Design and Nuclear Engineering, (1981), 159, McGraw-Hill.

（2）日本原子力学会編，原子炉に打省流動数值解析の現 状, (1986), 197.

（3）冨山・ほか 3 名, 機論, 59-566, B (1993)，3003.

(4) 富山・ほか 3 名, 機論, 57-539, B(1991), 1.

(5) Tomiyama A., ほか 3 名, JSME Int. J., 36-1(1993), 51.

(6) Tomiyama A., ほか 3 名, NED, 121 (1993), 69.

（7）冨山・宋・坂口, 機論, 60-575, B (1994), 2439.

（8）冨山・ほか3 名, 機講論, No. 914-2(1991-3)，86.

(9) Hirt C. W. and Nichols B. D., J. Comput. Phys., 39 (1981), 201.

(10) Nichols, B. D., Hirt, C. W. and Hotchkiss, R. S., LA8355(1980).

（11）安達，微分幾何学概説，(1976)，75，培風館.

(12) 冨山・平野, 機論, 58-551, B (1992), 131.

(13) Bhaga, D. and Weber, M. E., J. Fluid Mech., 105(1981), 61.

(14) Grace, J. R., Trans. Inst. Chem. Eng., 51 (1973), 116

（15）世古口・佐藤・本田, 機論, 40-333(1974), 1395.

(16) Liu, T. J., Proc. Inst. Conf. Multiphase Flows '91Tsukuba, 1(1991), 453.

（17）仮屋崎, 二相流シンポジウム講演論文集, (1985)，49. 